Crop Breeding and Applied Biotechnology 15: 265-271, 2015

Brazilian Society of Plant Breeding. Printed in Brazil

\title{
ARTICLE
}

http://dx.doi.org/10.1590/1984-70332015v15n4a44

\section{Intraspecific variability of camu-camu fruit in native populations of northern Amazonia}

Edvan Alves Chagas ${ }^{1 *}$, Ricardo Manuel Bardales Lozano ${ }^{2}$, Pollyana Cardoso Chagas ${ }^{2}$, Christinny Giselly Bacelar-Lima ${ }^{2}$, Maria Isabel Ribeiro Garcia ${ }^{2}$, Jaqueline Vilena Oliveira ${ }^{2}$, Olisson Mesquita Souza ${ }^{2}$, Bruna Santana Morais ${ }^{2}$ and Maria da Conceição da Rocha Araújo²

Received 15 April 2015

Accepted 29 June 2015

\begin{abstract}
Similarly to most breeding programs of native species, camu-camu (Myrciaria dubia (Kunt) McVaugh) improvement is also restricted, due to the scarcity of research results. In this situation, the prospection, collection and conservation of germplasm in genebanks ensure successful selection and breeding studies of the species. In this sense, the purpose of this study was the intraspecific characterization of the biometric variability in fruits of native camu-camu populations of the State of Roraima, in the northern Amazon region. Of 16 populations, 247 sub-samples were evaluated. Analyses were performed with the multivariate technique of principal components and hierarchical clustering, to determine the variables with highest intraspecific variability for the studied traits. The populations found in the lower Rio Branco region performed best for the studied traits, indicating the great potential of the region as a reservoir of promising subsamples for future breeding programs of the species in the northern Amazon.
\end{abstract}

Key words: Myrciaria dubia, breeding, selection, subsample, germplasm.

\section{INTRODUCTION}

Camu-camu (Myrciaria dubia (Kunth.) McVaugh) is a typical Amazonian fruit growing on river banks and lakesides throughout the Amazon basin (Zanatta and Mercadante 2007). The fruit pulp of this species is used for juices, jams and fermented products (Akter et al. 2011, Chagas et al. 2012). In some countries, camu-camu has aroused great interest in view of the high ascorbic acid content, i.e., from 845 to $6,100 \mathrm{mg}$ per 100g unprocessed pulp (Yuyama 2002). However, due to the high acidity, the fruits are rarely consumed fresh (Ribeiro et al. 2010). Fruit production and processing have become a viable alternative in the general development of fruit production in the Amazon, as a food source and a means of adding value to the natural resources available in the region (Welter et al. 2011, Neves et al. 2015). In the Amazon, more specifically in Roraima, the occurrence of native camu-camu populations in different parts of the State is significant.

The biometry of fruits provides important information about the genetic variability in populations of a same species and the relations with environmental factors (Penoni et al. 2011). However, native fruit species are heterogenous in vegetative and reproductive aspects and need to be studied to be establish selection criteria such as fruit color, size, width, etc. (Borges et al. 2010). These variations are important indicators of genetic variability to be exploited in breeding programs (Clement 2001). In this context, multivariate analysis techniques represent a viable option of analysis of the genetic variability in populations, for allowing multiple combinations of information within an experimental unit (Benitez et al. 2011).

Among these techniques, the most commonly used are: principal component analysis, analysis of canonical variables and the hierarchical clustering methods, which depend on the use of a previously estimated dissimilarity measure (Oliveira et al. 2003). The principal component analysis (PCA) consists of converting an original set of variables into another set of equal size, but with key properties, which are fundamental for certain breeding studies. The hierarchical cluster analysis is a multivariate

\footnotetext{
${ }^{1}$ Embrapa Roraima, Rod. BR 174, km 08, Distrito Industrial, 69.301-970, Boa Vista, RR, Brazil. *Email: edvan.chagas@embrapa.br

${ }^{2}$ Universidade Federal de Roraima (UFRR), Campus Cauamé, Rod. BR 174, Monte Cristo, 69.304-940, Boa Vista, RR, Brazil
} 
technique that assigns elements (variables) with maximum homogeneity within groups and differentiates the groups according to the greatest distance. This analysis is combined with PCA, since PCA can homogenize the data for a later cluster analysis of the resulting components (Balzarini et al. 2010).

Therefore, this study evaluated the intraspecific variability based on biometry of fruits of native camu-camu populations from the State of Roraima, northern Amazon, and determined the main traits for the selection of promising plants and for breeding programs.

\section{MATERIAL AND METHODS}

\section{Prospection and sampling}

A total of 247 sub-samples were collected from 16 native camu-camu populations in the State of Roraima and the local geographic coordinates were determined for each subsample (Figure 1), with a Garmin ${ }^{\circledR}$ GPS device. The geo-referenced data were processed with spatial analysis software DIVA-GIS, version 7.5 (http://www.diva-gis.org).

At sampling, the fruits were in the maturation stages 7 (green-reddish) and 8 (wine-red), according to Inga et al. (2001). Each population was labeled with a code consisting of the abbreviation of the river or creek catchment where which it was found (Table 1). At each sampling site, the mean sample size (n) was 15 and 60 fruits per sub-sample were collected, wrapped in polypropylene bags, placed in an ice-cooled polystyrene box, and taken to the laboratory at the end of the expedition.

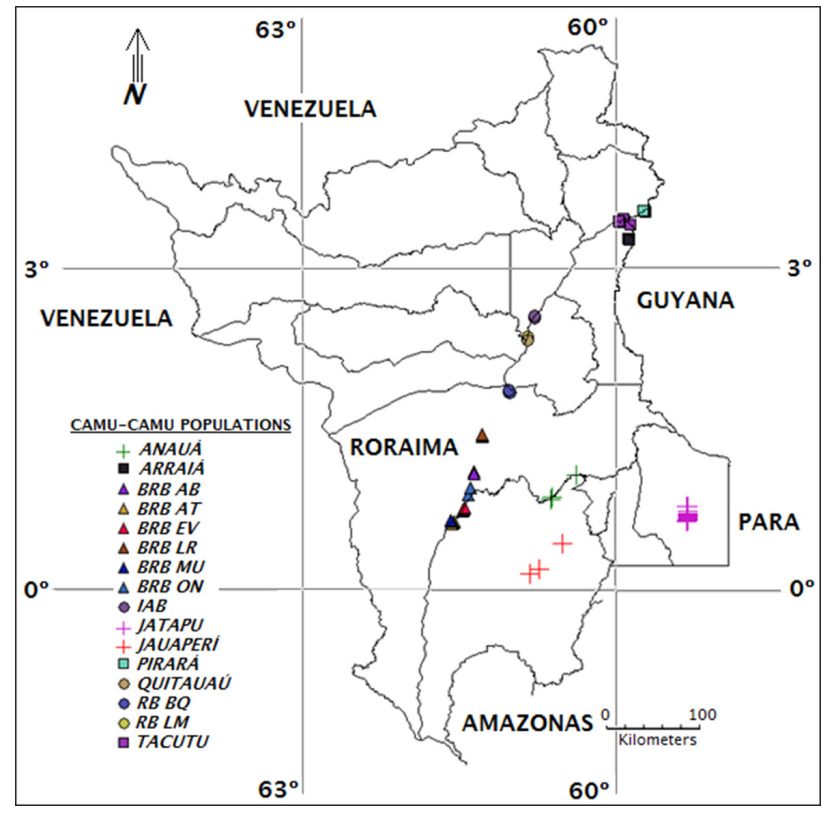

Figure 1. Georeferenced location of sampling points of subsamples of 16 camu-camu populations in the State of Roraima.

\section{Biometric physical, chemical and physic- chemical evaluations}

From each subsample, 30 fruits were picked at random and biometric, physical, chemical and physic-chemical analyses carried out to select the most promising genotypes. Thus, the mean fruit length (MFL) and mean fruit width (MFWi) were measured with a digital caliper and the data expressed in millimeter $(\mathrm{mm})$. The pulp, skin and seeds of each sample were weighed on an electronic scale, calculating

Table 1. Locations and catchments of natural camu-camu populations, found in the State of Roraima

\begin{tabular}{lccc}
\hline Population & Location & County & Catchment \\
\hline ARRAIA & Rio Arraia & Bonfim & Alto Rio Branco \\
PIRARA & Rio Tacutu- Igarapé (Ig.) Pirara & Normandia & Alto Rio Branco \\
RB LM & Rio Branco- Lago da Morena & Cantá & Alto Rio Branco \\
$T A C U T U$ & Rio Tacutu & Normandia & Alto Rio Branco \\
$I A B$ & Rio Mucajaí- Ig. Água Boa & Mucajaí & Alto Rio Branco \\
QUITAUAU & Rio Quitauaú & Cantá & Alto Rio Branco \\
RB BQ & Rio Branco- Bem Querer & Caracaraí & Médio Rio Branco \\
ANAUA & Rio Anauá & Rorainópolis & Baixo Rio Branco \\
$B R B A B$ & Rio Branco- Ig. Água Boa & Caracaraí & Baixo Rio Branco \\
$B R B A T$ & Rio Branco- Ig. Açaí Tuba & Baixo Rio Branco \\
$B R B E V$ & Rio Branco- Ig. Estirão do Veado & Caracaraí & Baixo Rio Branco \\
$B R B L R$ & Rio Branco- Lago do Rei & Caracaraí & Baixo Rio Branco \\
$B R B M U$ & Rio Branco- Lago Muçum & Caracaraí & Baixo Rio Branco \\
$B R B$ ON & Rio Branco- Ig. Onofre & Caracaraí & Baixo Rio Branco \\
$J A U A P E R I$ & Rio Jauaperí & Rorainópolis & Sub-Bacia Rio Negro \\
$J A T A P U$ & Rio Jatapu & Caroebe/Entre Rios & Sub-Bacia Rio Amazonas \\
\hline
\end{tabular}


the mean fruit weight (MFWe), and the data expressed in grams (g). By subtracting skin and seed weight from the total fruit weight, the pulp yield (PUY), skin yield (SKY) and seed yield (SEY) were calculated and expressed as percentages. The mean number of seeds per fruit (NSF) per subsample was also quantified, as recommended by Imán et al. (2011a). Soluble solids (SS) in the pulp were determined by a digital refractometer, and the amounts expressed in ${ }^{\circ}$ Brix. The ascorbic acid (AA) content was determined by the methodology of Tillmans (IAL 2008) and the results expressed in mg of ascorbic acid per 100 $\mathrm{mL}$ of sample.

\section{Statistical analysis}

For multivariate analysis, the data of each variable were standardized with zero mean and unit variance. The original data were subjected to principal component analysis (PCA), and with the PCA scores, the dissimilarity measure based on the Euclidean distance was calculated. The hierarchical method of average linkage between observation pairs, one per cluster, was used to group populations with similar performance in homogeneous sets (Balzarini et al. 2010). For the variables subjected to individual and combined analysis of variance, the population effect in the statistical model was considered random. The experimental design was completely randomized, and each subsample represented one replication. Estimates of means were grouped among populations by the Scott and Knott test (1974) at 5\% probability. Data were analyzed using uni- and multivariate statistical methods and the software InfoGen version 2013 (http://www.info-gen.com.ar).

\section{RESULTS AND DISCUSSION}

\section{Principal component analysis}

The Principal Component Analysis (PCA) was applied to observe the possible groupings within the camu-camu samples analyzed. According to the criterion of Cliff (1958), the first two principal components were selected, which together explained $75 \%(44 \%=\mathrm{PC} 1$ and $31 \%=\mathrm{PC} 2$, respectively) of the total variation (Figure 2).

As the PCA is a standard analysis, the coordinates of the variables for each component are equal to the correlation between the original variables on the two main axes (Balzarini et al. 2010).

The distribution of correlation coefficients (Table 2) indicated that the traits mean fruit length - MFL (0.91); mean fruit width - MFWi (0.90); mean fruit weight -MFWe (0.72); soluble solids - SS (0.65); ascorbic acid - AA (0.59); and pulp yield - PUY (0.44) contributed most and positively to the PC1, with a satisfactory degree of correlation, while the correlation with the mean number of seeds per fruit - NSF $(-0.68)$ and seed yield - SEY (-0.59) was inverse.

This component allows a discrimination of the populations associated with these traits on the $\mathrm{PC} 1$, for the populations from the affluents of the Rio Branco (BRB MU - Muçum, BRB ON - Onofre, BRB AT - Açaí Tuba, BRB EV - Estirão do Verão, BRB AB - Água Boa, RB BQ - Bem Querer), as well as the populations of the rivers Anauá, Jauaperí and Água Boa creek - IAB.

The second principal component (PC2) was mainly related to skin yield - SKY (0.89), ascorbic acid - AA (0.55) and seed yield - SEY (0.46) and inversely associated with pulp yield $(-0.88)$ and soluble solids - SS (-0.61). The populations associated to PC2 were the populations from the creek

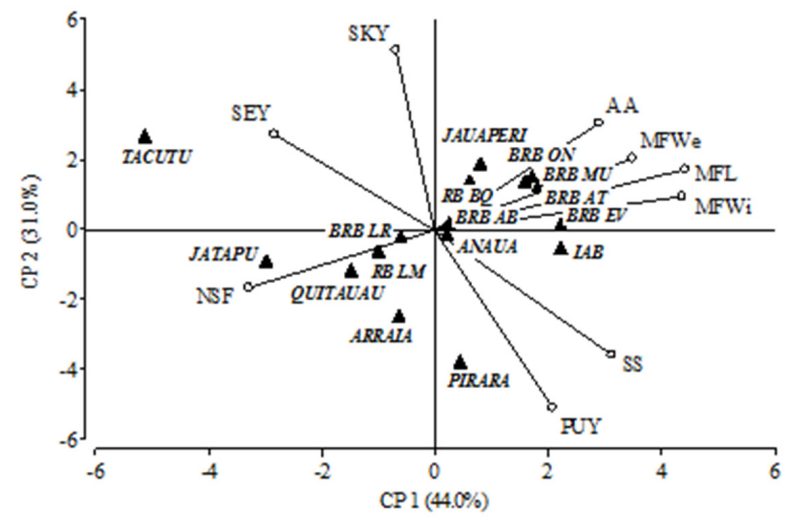

Figure 2. Principal component analysis of physical, chemical and physicochemical fruit traits of native camu-camu populations.

Table 2. Correlation matrix of the proper original variables and principal components in the study of camu-camu populations in the State of Roraima

\begin{tabular}{lcc}
\hline \multirow{2}{*}{ Variable } & \multicolumn{2}{c}{ Component } \\
\cline { 2 - 3 } & PC1 & PC2 \\
\hline MFL & 0.91 & 0.3 \\
MFWi & 0.9 & 0.16 \\
SEY & -0.59 & 0.46 \\
SKY & -0.16 & 0.89 \\
SS & 0.65 & -0.61 \\
NSF & -0.68 & -0.3 \\
MFWe & 0.72 & 0.35 \\
AA & 0.59 & 0.55 \\
PUY & 0.44 & -0.88 \\
\hline$\%$ Variance & 44 & 31 \\
\hline$\%$ Cumulative Variance & 44 & 75 \\
\hline
\end{tabular}

MFL - Mean fruit length; MFWi - Mean fruit width; MFWe - Mean fruit weight; PUY - Pulp yield; SKY - Skin yield; SEY - Seed yield; SS - Soluble solids; NSF Number of seeds per fruit; AA - Ascorbic acid content. 
Pirara and the rivers Jatapu, Quitauaú, Arraiá, and Tacutu. These results suggest that subsamples with high mean fruit skin yield may have higher ascorbic acid (AA) content, but lower pulp yield (PUY) and soluble solids (SS). Positive correlations between camu-camu fruit skin and high ascorbic acid levels were reported by Villanueva et al. (2010) and Imán et al. (2011b), in tests with fruits in three different maturation stages. These results allow the discrimination of populations and sub-samples based on the data of SKY, $\mathrm{AA}$ and PUY.

\section{Hierarchical cluster analysis}

The hierarchical cluster analysis (Figure 3), distinguished five groups. Group 1 (G1) consisted of the populations from the rivers Quitauaú, Anauá and Rio Branco (Lago da Morena - RB LM, Lago do Rei - BRB LR and Água Boa - BRB $\mathrm{AB})$, which were positively correlated with the traits NSF, SS, PUY and low correlated with MFL, MFWi and MFWe.

Group 2 (G2) contained mainly populations from the Rio Branco (Bem Querer - RB BQ, Açaí tuba - BRB AT, Muçum - BRB MU, Onofre - BRB ON, Estirão do Veado - BRB EV), river Jauaperí and creek Água Boa - IAB. In this group it was noted that the populations BRB ON and BRB MU were closest to each other. The variables that characterized them best were MFL, MFWi, MFWe and AA (Figure 2).

Group 3 (G3) clustered the populations of the river Arraia and Pirara creek, correlated with the traits PUY. Group 4 (G4) was composed of the population from the river Jatapu, which is positively characterized by high rates in the trait SEY (seed yield per fruit). On the other hand, group 5 (G5), containing the populations from the river Tacutu, was characterized by the greatest genetic distance from the other populations, highly correlated with NSF (mean number of seeds per fruit). The isolation of these latter two groups (G4 and G5) probably reflects their geographical distance from the other populations, indicated by the physical and physicochemical traits in the fruits (Table 3). According to the criterion of Balzarini et al. (2005), the data are generally very homogenous, since the highest group indices of the population were less than 3.0 away from each other (cutoff below $50 \%$ of the total distance).

\section{Analysis of variance}

The mean data of 9 physical and physicochemical fruit traits of the 16 camu-camu populations found in the State of Roraima were estimated (Tabe 3). The sources of variation of the populations were significantly different ( $\mathrm{p}$ $<0.01$ ) between traits, indicating high variability between the populations under study.

For MFL and MFWi (Table 3), the populations from the Rio Branco (such as Bem Querer - RB BQ (26.68; 26.06 mm), Açaí tuba - BRB AT (24.99; 26.49 mm), Estirão do Veado - BRB EV (24.88; 26.19 mm), Muçum - BRB MU $(24.81 ; 26.89 \mathrm{~mm})$, Onofre - BRB ON $(24.87 ; 26.26 \mathrm{~mm})$, igarapé Água Boa of the rivers Mucajaí - IAB (24.80; $26.49 \mathrm{~mm})$ and Jauaperí - RJI $(24.74 ; 25.70 \mathrm{~mm})$ ), differed significantly from the others, with higher mean values. These results were similar to those reported by Yuyama (2002) for the population of the Urubu river - RR, with MFL of $26.00 \mathrm{~mm}$ and MFWi of $26.8 \mathrm{~mm}$. This size is considered large for camu camu fruit, according to the description of the species in the literature (Yuyama et al. 2011).

For mean fruit weight (MFWe), the highest mean values were found for the populations of Bem Querer - RB BQ (11.51 g), creek Água Boa of the Mucajaí river - IAB (11.29 g) and Açaí tuba - BRB AT (10.95), which differed significantly from the others. These values agree with those reported in Peru by Imán et al. (2011a) for 43 camu-camu subsamples of the Germplasm Bank of the Brazilian institute of agricultural research INIA, with a mean of $11.47 \mathrm{~g}$. Similar results were reported by Yuyama (2002), with mean values between 9.46 and $11.35 \mathrm{~g}$ of the different subsamples. Mean values of $10 \mathrm{~g}$ were also reported by Inga et al. (2001). In the State of Roraima, Smiderle and Souza (2008) reported a mean of $11.80 \mathrm{~g}$ for ripe and $9.0 \mathrm{~g}$ for unripe fruit. The populations from the river Jatapu (8.51 g), Lago do Rei BRB LR (9.03 g) and river Quitauaú (9.09 g) had the lowest mean MFWe values.

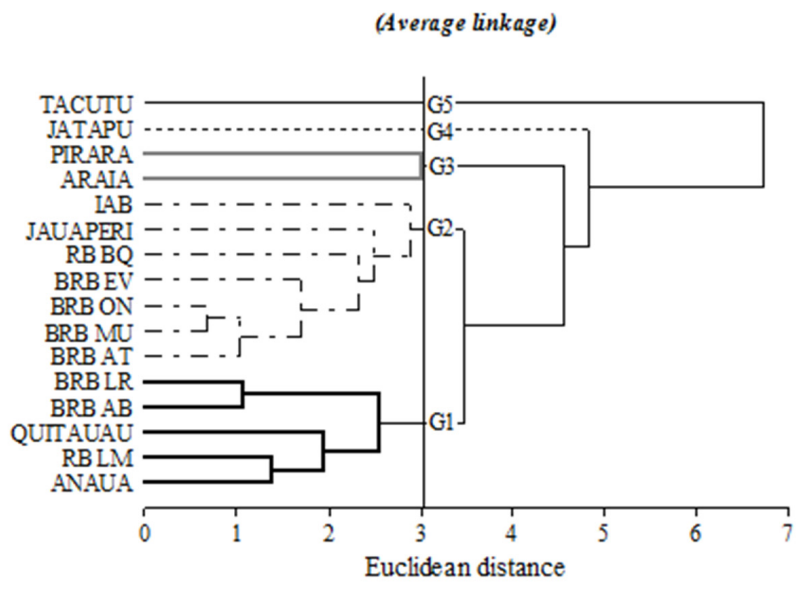

Figure 3. Dendrogram of classification of 16 camu-camu populations in Roraima, based on physical and physical-chemical traits of the fruits using the algorithm of means Average Linkage and the Euclidean distance. 
Intraspecific variability of camu-camu fruit in native populations of northern Amazonia

Table 3. Means of native camu-camu populations and coefficient of variation for mean fruit length (MFL, in mm), mean fruit width (MFWi, in mm), mean fruit weight (MFWe, in g), pulp yield (PUY, in \%), skin yield (SKY, in \%), seed yield (SEY, in \%), soluble solids (SS, in ${ }^{\circ}$ Brix), mean number of seeds per fruit (NSF) and ascorbic acid content (AA, in $\mathrm{mg} / 100 \mathrm{~g}$ of pulp+skin)

\begin{tabular}{|c|c|c|c|c|c|c|c|c|c|}
\hline \multirow{2}{*}{ Population } & MFL & MFWi & MFWe & SEY & SKY & PUY & NSF & SS & $\mathbf{A A}$ \\
\hline & \multicolumn{9}{|c|}{ Means } \\
\hline ANAUA & $23.91 \mathrm{a}$ & $24.95 \mathrm{~b}$ & $10.66 \mathrm{~b}$ & $22.1 \mathrm{~b}$ & $20.96 \mathrm{c}$ & $56.94 \mathrm{~b}$ & $1.55 \mathrm{~d}$ & $6.11 \mathrm{~d}$ & $5904.28 \mathrm{c}$ \\
\hline ARRAIA & $23.4 \mathrm{~b}$ & $25.83 \mathrm{a}$ & $9.83 \mathrm{c}$ & $24.25 \mathrm{~b}$ & $16.14 \mathrm{~d}$ & $59.61 \mathrm{~b}$ & $2,00 \mathrm{a}$ & $7.38 \mathrm{a}$ & $3953.72 \mathrm{f}$ \\
\hline BRB AB & $23.34 \mathrm{~b}$ & $25.03 \mathrm{~b}$ & $9.54 \mathrm{c}$ & $20.8 \mathrm{~b}$ & $23.82 \mathrm{~b}$ & $55.38 \mathrm{c}$ & $1.45 \mathrm{~d}$ & $6.79 \mathrm{~b}$ & $7319.40 \mathrm{a}$ \\
\hline BRB AT & $24.99 \mathrm{a}$ & $26.49 \mathrm{a}$ & $10.95 \mathrm{a}$ & $21.36 \mathrm{~b}$ & $24.22 \mathrm{~b}$ & $54.42 \mathrm{c}$ & $1.56 \mathrm{~d}$ & $6.24 \mathrm{~d}$ & $7084.97 \mathrm{a}$ \\
\hline BRB EV & $24.88 \mathrm{a}$ & $26.19 \mathrm{a}$ & $10.7 \mathrm{~b}$ & $18.72 \mathrm{c}$ & $23.97 \mathrm{~b}$ & $57.31 \mathrm{~b}$ & $1.64 \mathrm{c}$ & $7.15 \mathrm{~b}$ & $7355.20 \mathrm{a}$ \\
\hline BRB ON & $24.87 \mathrm{a}$ & $26.26 \mathrm{a}$ & $10.79 \mathrm{~b}$ & $20.62 \mathrm{~b}$ & $26.87 \mathrm{a}$ & $52.51 \mathrm{~d}$ & $1.53 \mathrm{~d}$ & $6.69 \mathrm{c}$ & $7041.77 \mathrm{a}$ \\
\hline $\mathrm{IAB}$ & $24.8 \mathrm{a}$ & $26.49 \mathrm{a}$ & $11.29 \mathrm{a}$ & $22.46 \mathrm{~b}$ & $20.06 \mathrm{c}$ & $57.48 \mathrm{~b}$ & $1.59 \mathrm{~d}$ & $7.87 \mathrm{a}$ & $5950.29 \mathrm{c}$ \\
\hline JATAPU & $22.58 \mathrm{c}$ & $23.88 \mathrm{c}$ & $8.51 \mathrm{~d}$ & $19.46 \mathrm{c}$ & $25.65 \mathrm{a}$ & $54.89 \mathrm{c}$ & $2.19 \mathrm{a}$ & $5.78 \mathrm{e}$ & $4976.95 \mathrm{e}$ \\
\hline JAUAPERI & $24.74 \mathrm{a}$ & $25.7 \mathrm{a}$ & $10.23 \mathrm{~b}$ & $22.17 \mathrm{~b}$ & $25.32 \mathrm{a}$ & $52.51 \mathrm{~d}$ & $1.23 \mathrm{~d}$ & $5.26 \mathrm{e}$ & $6554.36 \mathrm{~b}$ \\
\hline PIRARA & $23.6 \mathrm{~b}$ & $25.17 \mathrm{~b}$ & $9.77 \mathrm{c}$ & $17.5 \mathrm{c}$ & $16.88 \mathrm{~d}$ & $65.62 \mathrm{a}$ & $1.77 \mathrm{~b}$ & $7.65 \mathrm{a}$ & $3624.03 \mathrm{f}$ \\
\hline TACUTU & $22.17 \mathrm{c}$ & $23.73 \mathrm{c}$ & $9.52 \mathrm{c}$ & $30.18 \mathrm{a}$ & $28.24 \mathrm{a}$ & $41.57 \mathrm{e}$ & $2.07 \mathrm{a}$ & $4.29 \mathrm{f}$ & $4264.96 \mathrm{f}$ \\
\hline Overall mean & 23.88 & 25.34 & 10.15 & 21.8 & 22.99 & 55.2 & 1.67 & 6.39 & 5838.78 \\
\hline CV $(\%)$ & 7.61 & 7.86 & 20.77 & 16.36 & 19.47 & 11.87 & 19.94 & 12.75 & 13.9 \\
\hline
\end{tabular}

The data recorded for the fruit components indicate seed yield (SEY) values from $17.50 \%$ in the population of Igarapé Pirara, to $30.18 \%$ in the Tacutu River population, and an interpopulational mean of $21.80 \%$. These minimum and maximum values were higher than those found by Imán et al. (2011b), with 14.29 and $24.50 \%$ and an intraspecific mean of $19.84 \%$. These data differ from the intraspecific mean of Research Institute of the Peruvian Amazon germplasm, with a seed component of $25 \%$ of the fruit, reported by Pinedo et al. (2010).

With regard to the skin yield (SKY), there were minimum and maximum values of $16.14 \%$ in the Arraia river and $30.80 \%$ in the Tacutu river, with an intraspecific mean of $22.99 \%$, coinciding with the values reported in the national and international literature (Pinedo et al. 2010, Imán et al. 2011). This component is important because of the positive correlation with AA and negative correlation with PUY (Figure 2). In this context, Pinedo et al. (2004) mentioned that the identification of sub-samples with a mean pulp plus skin yield of 70 to $75 \%$ of the fruit weight should be a priority in camu-camu breeding programs.

The population Pirara had the highest mean pulp yield (PUY), with $65.62 \%$, differing significantly from the others. The population of the Tacutu River had the lowest mean PUY with $41.57 \%$. These results are similar to those recorded in Peru by Pinedo et al. (2001), with means of 48.0 to $55 \%$, differing from the results of Imán et al. (2011a), with 57.7 to $74.0 \%$ mean PUY. On the other hand, Andrade et al. (1995) observed mean PUY in sampled fruits from $53.00 \%$ to $82.00 \%$.

According to Calzada Benza and Rodriguez (1979/80), PUY can be increased or reduced by the amount of seeds per fruit and their maturation. The same authors mentioned that fruits with one seed produced $86 \%$, with two seeds $80 \%$, with three seeds $77 \%$ and with four seeds, $73 \%$ pulp yield. In other words, PUY is directly related to the number of seeds per fruit. This was confirmed for the Tacutu population, where the PUY value was lowest and the number of seeds per fruit highest (2.07).

The mean number of seeds per fruit (NSF) was highest in the populations of the rivers Tacutu (2.07) and Arraia (2.00), which differed significantly from the others. The overall intraspecific mean of the populations from Roraima was 1.67 seeds per fruit, similar to the mean reported by Smiderle and Souza (2008), of 1.50 seeds. These values were lower than results of other authors in the literature (Pinedo et al. 2001, Pinedo et al. 2004, Imán et al. 2011a), who reported mean intraspecific values of 2.50 and 2.86 seeds per fruit. The values found in this study may explain the good standards of PUY of the fruits from the State of 
Roraima.

Soluble solids (SS) content is one of the most important properties of market quality and of pulp use in product manufacturing (Yuyama and Aguiar 2011). The populations with the highest means were those from the creek Água Boa and river Mucajaí - IAB (7.87 ${ }^{\circ}$ Brix), of the creek Pirara ( $7.65^{\circ}$ Brix) and Arraia river (7.38 ${ }^{\circ}$ Brix), differing significantly from the other populations (Table 3 ). The mean intraspecific value was 6.39 , with minimum and maximum values between 4.29 and $7.87^{\circ}$ Brix.

The values of this study were close to those obtained by Silva et al. (2006), Imán et al. (2011a) and Akter et al. (2011) with, respectively $6.1,4.1-6.3$, and $6.4^{\circ} \mathrm{Brix}$, in the world literature. In Brazil, Zapata and Dufourt (1992) obtained mean Brix levels above $7.6^{\circ}$ Brix (mature) and below 4.95 ${ }^{\circ}$ Brix (immature). Zanatta and Merchant (2007) reported values of 6.5 to $8.5^{\circ}$ Brix and more recently, Yuyama and Aguiar (2011) found 6.20 to $8.97^{\circ}$ Brix.

The populations with highest ascorbic acid (AA) content were the populations of the lower Rio Branco region: $\mathrm{BRB}$ EV - Estirão do Veado (7355.20 mg), BRB AB - Água Boa (7319.40 mg), BRB AT - Açaí Tuba (7084.97mg), BRB ON - Onofre (7041.77 mg) and BRB LR - Lago do Rei $(6894.74 \mathrm{mg})$, followed by the populations BRB MU - Muçum (6564.57 mg) and from the Jauaperí river. The populations with the lowest levels were those along the rivers Tacutu (4264.96 mg), Igarapé Pirara (3624.03 mg) and Arraia (3953.72 mg). However, the levels differed, and were significantly higher in this study than reported elsewhere (Pinedo et al. 2001, Pinedo et al. 2004, Smiderle and Souza 2008, Imán et al. 2011b, and Yuyama and Aguiar 2011). On the other hand, these values are in line with those observed by Yuyama (2002), who describe that higher AA levels were extracted from the pulp plus skin portion of plants in the State of Roraima; the highest content was found in populations from the Urubu river $(5737 \pm 236.1$ $\mathrm{mg}$ ). The values recorded for AA identified populations and subsamples with better performance for this trait.

The studied camu-camu populations contained significant genetic variability that can be exploited for conservation and breeding of the species. Univariate and multivariate analyses indicated that mean fruit weight, pulp yield, soluble solids, and ascorbic acid are the most discriminating traits for intraspecific selection of native camu-camu. The populations from the lower Rio Branco region, i.e., BRB AB, BRB EV, BRB AT, BRB ON, and BRB LR, contained the highest ascorbic acid levels, representing a great reservoir of promising sub-samples for this trait. For the trait MFWe, the populations RB BQ and IAB were the most promising. The study populations showed that the genetic distance can be influenced by the geographical distance.

\section{Variabilidade intraespecífica de frutos de camu-camu em populações nativas na Amazônia Setentrional}

Resumo - Como a maioria dos programas de melhoramento de espécies nativas, o camu-camu (Myrciaria dubia (Kunt) McVaugh), apresenta limitações pelas escassas experiências de pesquisas. Dessa forma, a prospecção, coleção e conservação através dos Bancos de Germoplasma são uma garantia para a realização de trabalhos de seleção e melhoramento da espécie. Neste sentido, objetivou-se com o presente trabalho realizar a caracterização intraespecífica da variabilidade biométrica em frutos de populações nativas de camucamu, prospectados no estado de Roraima, Amazônia Setentrional. Foram avaliados 247 subamostras provenientes de 16 populações. As análises foram realizadas com auxilio da técnica multivariada de componentes principais e de agrupamento hierárquico. As análises permitiram determinar as variáveis que aportaram à maior variabilidade intraespecífica nas características avaliadas. As populações oriundas da região do baixo rio Branco apresentaram os maiores atributos nas características avaliadas, representando uma região com grande potencialidade na obtenção de subamostras promissores para futuros planos de melhoramento da espécie na Amazônia Setentrional.

Palavras-chave: Myrciaria dubia, melhoramento, seleção, subamostra, germoplasma.

\section{REFERENCES}

Akter MS, Oh S, Eun JB and Ahmed M (2011) Nutritional compositions and health promoting phytochemicals of camu-camu (Myrciaria dubia) fruit: A review. Food Research International 44: 1728-1732.

Andrade JS, Aragão CG, Galeazzi MAM and Ferreira SAN (1995) Changes in the concentration of total vitamin $\mathrm{C}$ during maturation and ripening of camu-camu (Myrciaria dubia) fruits cultivated in the upland of Brazilian Central Amazon. Acta Horticulture 370: 177-180.
Balzarini M, Bruno C and Arroyo A (2005) Análises de ensayos agrícolas multi-ambientales. Aplicaciones en Info-Gen. Grupo de Editores, Córdoba, $153 \mathrm{p}$.

Balzarini M, Bruno C, Peña A, Teich I and Di Rienzo JA (2010). Estadística en biotecnología. Aplicaciones en Info-Gen. Grupo de Editores, Córdoba, 250p.

Benites LC, Rodrigues ICDS, Arge LWP, Ribeiro MV and Braga EJB (2011) Análise multivariada da divergência genética de genótipos de arroz sob estresse salino durante a fase vegetativa. Revista Ciência 
Agronômica 42: 409-416.

Borges KCDF, Santana DGD, Melo BD and Santos CMD (2010) Rendimento de polpa e morfometria de frutos e sementes de pitangueira-do-cerrado. Revista Brasileira de Fruticultura 32: 471-478.

Calzada Benza JC and Rodriguez RJ (1979/80) Investigaciones sobre el Camu-Camu (Myrciaria paraensis Berg). Editora INIA, Iquitos, 15p.

Chagas EA, Bacelar-Lima CG, Carvalho ADS, Ribeiro MIG, Sakazaki TR and Neves LC (2012) Propagação do camu-camu (Myrciaria dubia (H.B.K.) Mc vaugh). Agro@mbiente 6: 67-73.

Clement CR (2001) Melhoramento de espécies nativas. In Nass LL, Valois ACC, Melo IS and Valadares-Inglis MC (Ed) Recursos genéticos \& melhoramento - plantas. Editora Fundação MT, Rondonópolis, p. $423-441$.

Cliff N (1958) The eigenvalues-greater-than one rule and the reliability of components. Psychological Bulletin 103: 276-279.

Imán S, Pinedo S and Melchor MM (2011a) Caracterización morfológica y evaluación de la colección nacional de germoplasma de camu camu Myrciaria dubia (H.B.K) Mc Vaugh, del INIA Loreto-Perú. Scientia Agropecuaria 2: 189-201.

Imán, S, Zamudio BL, Sotero SV and Oliva CC (2011b) Contenido de vitamina C en frutos de camu camu Myrciaria dubia (H.B.K) Mc Vaugh, en cuatro estados de maduración, procedentes de la Colección de Germoplasma del INIA Loreto, Perú. Scientia Agropecuaria 2: 123-130.

Inga H, Pinedo M, Delgado C, Linares C and Mejía K (2001) Fenologia reprodutiva de Myrciaria dúbia Mc Vaugh (H.B.K.) camu camu. Folia Amazónica 12: 99-106.

Instituto Adolfo Lutz-IAL (2008) Métodos físico-químicos para análise de alimentos. Editora IAL, São Paulo, 1020p.

Neves LC, Silva VX, Chagas AE, Bacelar-Lima CG and Roberto SR (2015) Determining harvest time of camu-camu (Myrciaria dubia H.B.K. McVaugh) using measuring pre-harvest attributes. Scientia Horticulturae 186: 15-23.

Oliveira FJ, Anunciação Filho CJD, Bastos GQ and Reis OVD (2003) Divergência genética entre cultivares de caupi. Pesquisa Agropecuária Brasileira 38: 605-611.

Pinedo M, Linares C, Mendoza H and Anguiz R (2004) Plan de mejoramiento genético de camu camu. Editora IIAP, Iquitos, 54p.

Pinedo PM, Delgado DC, Farroñay PR, Castillo T, Imán CS, Villacrés VJ, Fachin ML, Oliva CC, Abanto RC, Bardales LR and Vega VR (2010) Camu-camu (Myrciaria dubia, Myrtaceae): Aportes para aprovechamiento sostenible en la Amazonía peruana. Editora Talento G Sac, Lima, 137p.

Pinedo PM, Riva Ruiz R, Rengifo SE, Delgado VC, Villacrez VJ, González CA, Inga SH, López UA, Farroñay PR, Vega VR and Linares BC (2001) Sistema de producción de camu camu en restinga. Editora IIAP, Iquitos, 143p.
Pinedo S, Imán S, Pinedo M, Vasquez A and Collazos H (2011) Clonal trial of five genotypes of "camu-camu", Myrciaria dubia (h.b.k) mc. Vaugh, in non-flooded area. African Journal of Plant Science 5: 40-46.

Penoni ES, Pio R, Rodrigues FA, Maro LAC and Costa FC (2011) Análise de frutos e nozes de cultivares de nogueira-macadâmia. Ciência Rural 41: 2080-2083.

Ribeiro OD, Nascimento WMO e Almeida EGL (2010) Caracterização morfolôgica de plantas em acessos de camucamuzeiro do Banco de germoplasma da Embrapa Amazônia Oriental. Embrapa, Belém, 4p.

Scott A and Knott M (1974) Cluster-analysis method for grouping means in analysis of variance. Biometrics 30: 507-512.

Silva MA, Sobral PJA and Kieckbusch TG (2006) State diagrams of freezedried camu-camu (Myrciaria dubia (HBK) McVaugh) pulp with and without maltodextrin addition. Journal of Food Engineering 77: 426-432.

Smiderle OJ and Souza RPD (2008) Teor de vitamina C e características físicas do camu-camu em dois estádios de maturação. Revista Agro@ mbiente On-line 2: 61-63.

Villanueva T, Condezo-Hoyos L and Ramírez E (2010) Antocianinas, ácido ascórbico, polifenoles totales y actividad antioxidante en la cáscara de camu camu Myrciaria dubia (H.B.K.) Mc Vaugh. Revista Ciencia y Tecnología de Alimentos 30: 151-160.

Welter MK, Melo FV, Bruckner CH, Góes HTP, Chagas AE and Uchôa SCP (2011) Efeito da aplicação de pó de basalto no desenvolvimento inicial de mudas de camu-camu (Myrciaria dubia H.B.K. McVaugh). Revista Brasileira de Fruticultura 33: 922-931.

Yuyama K (2002) Camu-camu: um fruto fantástico como fonte de vitamina C. Acta Amazônica 32: 169-172.

Yuyama K, Yuyama LKO, Valente JP, Silva ACD, Aguiar JPL, Flores WBCH, Bacelar-Lima CG, Espírito-Santo MLD, Koshikene D and Gonzalez SR (2011) Camu-camu. Editora CRV, Curitiba, 216p.

Yuyama LKO and Aguiar JPL (2011) Composição e valor alimentar. In Yuyama K and Valente JP (eds) Camu-camu. Editra CVR, Curitiba, p. 125-134.

Yuyama LKO, Aguiar JPL, Yuyama K, Lopes TM, Fávaro DIT, Bergl PCP and Vasconcellos MBA (2003) Teores de elementos minerais em algumas populações de camu-camu. Acta Amazonica 33: 549-554.

Zanatta C and Mercadante A (2007) Carotenoid composition from the Brazilian tropical fruit camu-camu (Myrciaria dubia). Food Chemistry 101: 1526-1532.

Zanatta CF, Cuevas E, Bobbio FO, Winterhalter P and Mercadante AZ (2005) Determination of anthocyanins from camu-camu (Myrciaria dubia) by HPLC-PDA, HPLC-MS, and NMR. Journal of Agricultural and Food Chemistry 53: 9531-9535.

Zapata SM and Dufour JP (1992) Camu-camu Myrciaria dubia (H.B.K) Mc Vaugh: Chemical composition of fruit. Journal of Science Food Agriculture 61: 349-351. 